\title{
Home Court Advantage in Basketball - A Case Study of Žalgiris Kaunas Basketball Team
}

\author{
By Mindaugas Gobikas ${ }^{*}$, Alexandru Radu ${ }^{ \pm}$\& Jonas Miklovas ${ }^{t}$
}

The actual venue where a basketball game is played needs to be considered (Volossovitch 2017) when looking at the effectiveness of a team's performance playing in front of home crowd. Clarke (2005), Gomez and Pollard (2011) and Bray and Widmeyer (2008) explored the home court advantage topic and argued that this exists and is influenced by various factors (such as familiarity with environment, crowd support and loud arena, shooting percentages, absence of travel, etc.). A top division professional basketball team from Lithuania (Žalgiris Kaunas) was selected for this study using a convenience sample method (Veal and Darcy 2014). A case study approach (which incorporated comparisons between and an analysis of certain statistical categories such as: points scored per game; points allowed per game; free throws - made and attempted per game; 3 points shots - made and attempted; assists and turnovers) were used as part of this investigation into Žalgiris Kaunas basketball team and the games they played at home during 2017-2018 and 2018-2019 seasons. From a methodological point of view, a three stage approach was employed. First stage was an exploratory analysis of relevant data available in the public domain for the selected team /club. Second stage comprised of an initial analysis that consisted of statistical calculations (averages per game and per season) and comparisons between Žalgiris Kaunas and their opponents while a discussion and concluding analysis - as a third stage - was drawn by interpretation of data. Similar to findings from literature, playing at home in front of full capacity crowd was beneficial for Žalgiris Kaunas as their performances improved for the statistical categories previously mentioned, alongside with being victorious in 11 out of the 19 home games that were scrutinised for the purpose of the research.

Keywords: home court advantage, basketball performance indicators, basketball analytics, attendance, Žalgiris Kaunas

\section{Introduction}

"The home advantage in sports is real" (p. 351) argues Smith (2005). However, the causes are not yet fully known (Yi 2017). Since 1977, when one of the first articles discussed the home advantage topic in the context of team sports (see Schwartz and Barsky 1977), the literature in this field has grown substantially and received lots of attention from both the academic world, players, fans and mass media alike. As a well-established phenomenon (Yi 2017, Koning 2011) and "intriguing phenomenon" (Gomez and Pollard 2011, p. 143), home advantage has

\footnotetext{
* Lecturer, Institute of Leadership and Strategic, Mykolas Romeris University, Lithuania.

${ }^{ \pm}$Senior Lecturer, University of Worcester, UK.

${ }^{\ddagger}$ Editor in Chief, Basketnews.lt, Lithuania.
} 
been the topic for numerous researchers who scrutinised and who tried to explain if the team (or the athlete) playing at home benefits of any kind of advantage. Watkins (2013) asserts the acceptance from both players and their fans that in majority of sporting events a "systematic advantage does exist for the home team" (p. 34). Specifically for basketball, the home court advantage is visible for Kozy (2011) as in any other sport and his investigation proposed a model using a mathematical approach. Furthermore, playing at home brings an advantage of 4.68 \pm 0.28 points as estimated by Harville and Smith (1994). Basketball as a sport is amongst the few sports that actually allow one team to play more games on own court - this is the case in competitions such as NBA or Euroleague when the teams qualify for the play-off stage (the higher placed team out of the top eight finishers at the end of the regular season has the advantage of playing on home court in the decisive game in best out of 3 , out of 5 or best out of 7 series).

This paper intends to contribute to this body of knowledge and, by using a case study approach (by specifically looking at home court attendances of Žalgiris Kaunas basketball team and at statistical data from these particular games played at home in the Euroleague competition) to assess the impact that home crowd support has on the performance of the team (with data collected and interpreted for 2017-2018 and 2018-2019 seasons) in respect of winning and losing games. The specific statistical information relates to game-relevant categories such as: points per game (scored and allowed); free throws (made and attempted); 3 points (made and attempted); number of assists; and number of turnovers; for both the home team (Žalgiris Kaunas) and their opponents.

The paper is structured in an easy to follow manner. The first section will outline relevant literature review; it will start with an overview of research pertaining to the various factors of home court/field advantage in sports. More specific and, in particular, relevant factors to this study, such as the impact of basketball arena to the performance of home team, will be summarized as well. A brief overview of the origins as well as the contemporary status of sports analytics will be presented towards the end of section one, followed by a paragraph designated for the demonstration of the latest research in basketball analytics.

The second section of this article contains the research methods (and generally, the methodological approach which was undertaken), while the third section is devoted to the research findings and a discussion, taking into account the existing opinions expressed by various researchers (in both European and North American basketball context). The final section of this paper provides conclusions. As it will be illustrated, the main findings support the idea of home court advantage in basketball. Analytic analysis of this research showed that the capacity or near capacity crowd led to home team's increased efficiency, which in turn led to more wins (for the particular team that was investigated). 


\section{Literature Review}

Definition/Various Factors that Impact on and Explanations of Home Court Advantage

Clarke (2005) mentions Pollard's definition (1986) who argued that home advantage can be measured by looking at the number of games won by teams playing on home court and expressing it as a percentage of all the games played. In his study based on Australian rules football, Clarke (2005) found that $80 \%$ of matches he investigated "carried a perceived home advantage" (p. 378). Coincidentally, Koning defined the home advantage concept in the same year (2005) and stated that "home advantage is the performance advantage of an athlete, team or country when they compete at a home ground compared to their performance under similar conditions at an away ground" (p. 422).

Several factors and explanations were identified as having an impact on and contributing to teams and players obtaining home advantage: home crowd, familiarity, travel (Courneya and Carron 1992); the style of play (Harris and Roebber 2019, based on their study on NBA teams); crowd support, familiarity with local circumstances, fatigue (or the lack of it) and specific rules that favour either the home or away team (Koning 2011); learning factors, travel and crowd factors including the support from the home crowd and even referee bias (Clarke 2005).

Smith (2005) also identifies the fans as being "partly responsible for producing any success" for the home team (p. 356) and he also adds officials, territoriality and psychological state on the list of contributors to home advantage. Additionally, Yi (2017) argues that teams tend to play in a more aggressive manner when playing at home.

\section{Research in Basketball - Specific Examples}

Jones (2018) argues that the advantage in basketball exists in the college game as well as in the NBA. Similar situation was proved for European basketball - the results from a study conducted by Gomez and Pollard (2011) confirmed "the existence of home advantage effect" (p. 143) after investigating seven professional basketball leagues in Europe; and came to reinforce similar findings from their previous study in 2007.

Bray and Widmeyer (2008) investigated Canadian basketball at women's intercollegiate level in an attempt to explore athletes' perceptions of the home advantage. Amongst their findings was that the greatest influences on performance of the team were familiarity of /with the home court and home crowd support, alongside with the athletes' belief that "there was a substantial home advantage in their league of greater than $60 \% "$ (p. 7). A very similar home winning percentage $(60.9 \%)$ was presented by Madrigal and James (1999) after their investigation on women's college basketball in North America. Furthermore, a 64.4\% home winning percentage for men and $54.4 \%$ for women was the finding of a study in which Moore and Brylinsky (1995) analysed the home advantage in collegiate 
basketball in the Mid-American Conference in USA. Additional findings support these figures/percentages with different research showing that home teams win on average more games, ranging from 50\% (Courneya and Carron 1992, Nevill and Holder 1999) to 66\% (Snyder and Purdy 1985) of games are won by home teams.

Other studies looked at the rest between road games for visiting teams in order to find out if there is any correlation - for example, Entine and Small (2008) discovered that rest (and the impact of fatigue) positively related to both the size of the average margin of victory for home teams and the percentage of games won by home teams. Same authors argue that NBA, as a league, has the largest home advantage of any of the major team sports leagues considering the games they investigated during 2004-2005 and 2005-2006 seasons. The following paragraph will delve into the specifics of home arena and its impact on home team performance.

\section{Loud Arena}

The idea of playing in a "loud arena" or in a "difficult place for road teams" (p. 357) was highlighted by Smith in his study in 2005 when he scrutinised fans views in the North American basketball context. Other authors seem to agree by saying that difficult venues and the home crowd "stun the visitors" (Pomeroy, 2012), daunts and disheartens the away players (Jones 2013); while it energises the home team (Pomeroy 2012) and motivates and inspires the home players (Jones 2013). The crowd, as stated by Jones (2013), is the $6^{\text {th }}$ man in basketball (or, using an example from another sport, the $12^{\text {th }}$ man in American football).

McAndrew (1992) adds that the noise created by the home crowd at inopportune moments during the game might disrupt the communication between away team players and it might distract and impair certain aspects of their performance, affecting in this way the overall team performance. On a same note, Garcia et al. (2015) discovered that an increase on game attendance had a direct effect in the number of victories obtained by the home teams (in their study based on NBA teams between 2007-2013 during the regular seasons).

Since moving to a new arena (Žalgirio Arena), Žalgiris Kaunas basketball team' supporters managed to create a supportive atmosphere for their team, determining Eurohoops to consider it the toughest arena to play at after surveying 67 Euroleague players (and getting 40\% of the votes) (Źalgiris Kaunas 2019, Eurohoops.net 2019). Real Madrid Head Coach Pablo Lasso agreed when discussing playing in this arena before one of his games: "it is a difficult place to go and play and the atmosphere can be intense, their fans really get behind them" (Real Madrid 2019).

Within this large and the most spacious venue in the Baltic countries (Zalgirioarena.lt 2011), passionate and knowledgeable fans produce an intimidating atmosphere which is "often hailed as one of the top in Europe" (Talkbasket.net 2019). The team moved from Kauno Sporto Halle and started playing their home games at Žalgirio Arena. Since $18^{\text {th }}$ August 2011 when it opened its doors (Talkbasket.net 2019), numerous games were sold out with people from all over Lithuania and beyond filling all the 15415 seats available 
(Zalgirioarena.lt 2020). Interestingly, a statistic published by Runrepeat.com (2019) shows that 5\% of Kaunas population is going to the Arena for every game to support and follow the team. This level of support leads to another attentiongrabbing fact: $95 \%$ of the arena is filled with fans every single game and because of this Žalgiris Kaunas basketball club joins Maccabi Tel Aviv as the leaders of the Euroleague basketball competition in this particular category (fans attendance) (Runrepeat.com 2019).

The following sub-section will present an overview of sports analytics. It will first provide an insight into the origins of this field as well as its rather sudden proliferation over the past few decades. Finally, more specific examples of research in the basketball analytics domain and their relevance to the current study will be discussed and presented.

\section{Sports Analytics}

Sports analytics is a rapidly growing industry. It refers to the use of data and advanced statistics to measure performance and make informed decisions, in order to gain a competitive sports advantage. The use of sports analytics is designed to improve player and game performance, enhance organization's business performance and analyze player health and injury probability. However, in the future the scope of sports analytics reach will only broaden as "sports analytics can be used in innumerable types, such as social engagement, performance biomechanics analysis, psychological and physical metrics and the aforementioned critical analysis of advanced sports statistics so that technical staff and domain experts can understand more the game and improve the processes and methodologies" (Sarlis and Tjortjis 2020, p. 17).

With an immediate popularity of bestselling book Moneyball (Lewis 2003), baseball was the first sport to seriously incorporate the usage of advanced statistics. And such antecedence was to no surprise because baseball is the easiest team sport to model with mathematics. The game can be reasonably partitioned into a series of discrete events and the contributing players in each event can be easily identified and isolated. On the other hand, basketball is fluid. Here each event most often is the result of a series of contributions from all players on the floor. More importantly, a number of contributing factors - such as screens away from ball, hustle plays or help defence for example - go unregistered by the game statistics. Thus, use of analytics and big data paved the way for unprecedented, novel and creative avenues for sports understanding.

\section{Sports Analytics in Basketball}

Mostly pioneered by Houston Rockets (National Basketball Association (NBA) team) general manager Daryl Morey, analytics in basketball has been gaining more prominent role over the past two decades. As mentioned earlier, its primary purpose is to assist with decision making in player and team performances. Additionally, the use of analytics has spread into managerial and business operations of basketball teams as well. Harrison and Bukstein (2017) outline in great details how the use of analytics can help with market research analysis, 
customer relationship management, social media engagement, and sports sponsorship. Ticket sales, nevertheless, garner the most attention of analytics research in the management side of sport organizations (Mondello and Kamke 2014). More importantly, another research proves that the use of analytics is an effective managerial tool, which indeed provides substantial benefits. As Troilo et al. (2016) conclude the use of analytics lead to $7.2 \%$ revenue growth.

Performance analysis is by no means a new phenomenon in sports science studies. However, what is new is an abundance of a more sophisticated and more robust data, as well as tools for data collection. As a result, coaches, managers and even athletes themselves can obtain more detailed performance evaluations, training techniques in order to make better decisions. The NBA has drawn significant amount of scholarly attention regarding the studies of individual player talent evaluation or player performance evaluations as well as team compositions and analysis (Shea and Baker 2013, Glockner 2016). More exclusive examples of analytics capabilities in basketball are presented by Franks et al. (2015) or Bocskocsky et al. (2014). The former attempted to demonstrate how defensive performance (which traditionally lacks statistical information in comparison to offensive performance) could be analyzed and measured. While the latter tackled an even more unconventional topic - the likelihood of a "hot hand", a purported phenomenon that a person who experiences a successful outcome has a greater chance of success in further attempts. On the same topic, Castel et al. (2012) claimed that older adults believed in hot hand by adding some light into this topic which anecdotally received lots of support from players, coaches and even from fans (Ross 2017). Ross (2017) actually looks at both sides of the story and cites authors that argue hot hand is a "massive and widespread cognitive illusion" (Kahneman 2011, cited in Ross 2017, p. 145).

All these authors pointed out that such phenomenon may in fact be true among the NBA and college players. The outlined examples are just a glimpse of inexhaustible opportunities big data and analytics create for sports managers and academics. While, as seen, most of the research has focused exclusively on either side of sport organizations (business or sports performance), this research aims to combine the off-court side (attendance, ticket sales) and the on-court side (scoring, winning) of basketball. Kaplan et al. (2019) provided an example of an attempt to incorporate both sides by estimating that the absence of team superstars had an impact of up to $25 \%$ on ticket prices. The research presented in this paper has combined data of business and on-court performance and attempted to find the correlation between home-court and team wins. The methods that were employed during this study will be explained in the next section.

\section{Methodology}

A case study design (Jones and Gratton 2015) was considered the best approach in order to understand the dynamics of the team performance in relation to their home crowd (and the impact which the crowd support might have on the outcome of the game). A top division basketball team from Lithuania (Žalgiris 
Kaunas) was selected for this study using a convenience sample approach (Veal and Darcy 2014). The team competes in highest ranked European basketball competition - the Euroleague. Data from two seasons (2017-2018 and 2018-2019) was collected, compiled and analyzed. Žalgiris Kaunas team led the Euroleague in home attendance numbers during both of those seasons registering 13,560 and 14,808 average crowds respectively (Basketnews.lt 2020). However, in order to evaluate home court advantage, a decision was made that only home games in which attendance exceeded the average attendance of a given season, were selected for this study. As a result, the present case study is composed of 19 games in total.

From a methodological point of view, a three stage approach was employed. First stage was an exploratory analysis of relevant data available in the public domain for the selected team /club. Using data bases of the official Euroleague website (Euroleague.net), as well as basketball related websites (Basketnews.lt 2020, Overbasket.com 2020), several statistical categories such as points per game scored, points per game allowed, free throws (made and attempted), 3-points (made and attempted), assists, turnovers, and possessions were compiled and analyzed. Second stage comprised of an initial analysis that consisted of statistical calculations (averages per game and per season) and comparisons between Žalgiris Kaunas and their opponents while a discussion and concluding analysis - as a third stage - was drawn by interpretation of data (in the light of existing literature and previous research on the topic). Specific reference was made not only to free throws and 3 points shots percentages but also to assists and turnovers as the literature suggests teams that score consistently good percentages have a chance to win the match and /or the league they are part of (during both regular season and also play-off stages).

\section{Results and Discussion}

Žalgiris Kaunas played 19 home games in both 2017-2018 and 2018-2019 seasons - full details are presented as part of Appendix 1 including: name of opposite team; final result; attendance numbers /spectators per game; free throws totals (made and attempted) per game for opponents and for Žalgiris team; and 3 points shots (made and attempted) for opponents and for Žalgiris team. As mentioned previously, the team led the Euroleague in attendance during both of those seasons. Such high attendance numbers could be attributed to the fact that basketball is the most popular sport in Lithuania and Žalgiris being not only the city's team but a team that the entire country supports. Also, both seasons produced succesful results on court, as the team made the play-offs and even reached the Euroleague Final Four tournament in 2018 (Euroleague.net, 2020c).

Nineteen home games (10 in 2017-2018 season and 9 in 2018-2019 season) produced attendance which was higher than the average of that respective season. 11 of those games ( 8 in 2017-2018 season and 3 in 2018-2019 season) were wins $(57.9 \%)$. Only statistics from those games were used for this study and the findings are presented further down below. 
Generally speaking and after careful analysis of the data, the numbers relevant to Žalgiris performance for the seasons being investigated support the idea that teams perform better at home. This study provides ample evidence to support such notion - the main findings will be grouped under the headings of points per game and free throws; 3 points; assists, turnovers and other relevant statistics further down below.

Points per Game (PG) and Free Throws (FT)

Žalgiris Kaunas scored more points per game than both season and home averages, especially during wins (+5.7); additionally, the team allowed fewer points, especially during wins (-5.8).

Free throws would be another part of the spectrum for the most efficient ways to score in basketball. It is the highest percentage shot and most teams average well above 70 percent. It is an uncontested shot, giving the fouled player a chance to earn the points that were potentially taken from him because of the foul. And, most importantly, the game clock is stopped at the time of free throw shooting. Oliver (2004) identified free throw shooting among the top four factors of basketball success (along with field shooting, turnovers and rebounding) and assigned a 15 percent weight towards overall result. Similarly, Sampaio (2003) argued that around 20 percent of a team's total score can come from the free throw line. Glockner (2016, p. 61) convincingly observes that "visits to the "charity stripe" remain the sport's most efficient offensive trip". Further analysis of the statistics on free throw shooting for both 2017-2018 and 2018-2019 Euroleague seasons supported the idea of correlation between free throws and winning. The top four teams that made to the Final Four tournament were among top 5 (in 201718 season) and among top 10 (in 2018-2019 season) in the league in free throws attempted. In fact, teams that led the league in free throw attempts ended up winning the championship in respective seasons (Euroleague.net 2020b).

\section{Points (3 PTS)}

As contemporary basketball is increasingly more reliant on 3-points shot as it brings a valuable contribution to the team success (for 3-points shot as a game performance indicator see, for example, the findings of Garcia et al. 2013), it was important to investigate the effect that home crowd has on long range shooting and the relationship between the two. The research showed that Žalgiris attempted and made more 3-point shots, especially during wins (+1.8 during 2017-2018 season; +1.8 during 2018-2019 season). More importantly, Žalgiris managed to hold its opponents to lower numbers in both made and attempted 3-point shots, fact that increases their chance of winning the game.

Assists (AST)

In terms of better team communication, which could be enabled by home court advantage and familiarity (and which could be easily disturbed by the loud 
noise produced by the spectators within the arena), team assists could be an indication of such variable. As a vital statistical indicator, the assist was identified by Gomez et al. (2008) and Melnik (2001) as one of the discriminating factors between teams and between winning or losing a game. A similar point was raised by Dogan et al. (2016) who included assists as an important game-related statistical category that has a great impact on the team's success.

The present analysis showed that Žalgiris Kaunas had a little bit more assists than season average, but less that season home average. However, the team had significantly more assists during wins $(+3)$. Also, the team had fewer turnovers, especially during wins (-2.9).

\section{Turnovers (TO)}

It can be argued that the atmosphere created by the fans that spectate the games adds additional pressure on the execution of different plays, technical elements, etc. leading to decision making which both the assists (good decision making) and the turnovers (poor decision making) rely heavily on (as pointed out by Garcia et al. 2013). A small (or limited) number of turnovers for own team clearly increases the chances of winning the game and this should be the main focus of the team in offence (Fylaktakidou et al. 2011); conversely, getting the opposite team into committing errors when handling the ball and running plays is one important aim for any team. Such an important measure of performance (the number of turnovers) increases the chances of defeat - the higher the number of turnovers the higher the chances to lose as Ibanez et al. (2003) argue.

The fact that Zalgiris had more turnovers (-1.4) compared to their opponents $(-0.4)$ can be explained by the level of pressure experienced - playing in front of own fans and trying to match their high expectations leads to additional pressure (on the top of the one provided by the opposite team, on court) and consequently to making mistakes. To support this point, Sampaio and Janeira (2003) claimed that the number of turnovers produced by winning home teams was higher when compared to losing home teams (for both regular season and play-off games). Having said that, this category alone did not lead to Žalgiris losing games as they compensated in all other categories as discussed above.

The following research findings comprise of statistical data from Žalgiris opponents. It will be accompanied by the analytical analysis of Žalgiris efficiency - widely recognised as the most important indicator of winning performance.

\section{Summary of Relevant Statistics for Žalgiris Opponents}

The summary (for full details see Table 1) of Žalgiris opponents' statistics provided similarly supportive numbers:

- The opponents scored fewer points than their season averages (-2.8), especially during Žalgiris wins (-7.1).

- The opponents allowed more points than their season average $(+3.6)$, especially during their losses $(+6.5)$. 
- The opponents attempted more 3-point shots $(+1.6)$ and made slightly more 3-point shots (+0.2), but made fewer during Žalgiris wins (-0.9).

- The opponents attempted fewer (-2) and made fewer (-1) free-throw shots during Žalgiris wins.

- The opponents had more assists (+0.5), but fewer during Žalgiris wins ($0.2)$.

- The opponents had fewer turnovers $(-0.4)$.

Table 1. Key Statistical Categories of Žalgiris Kaunas and its Opponents (20172018 and 2018-2019 Seasons)

\begin{tabular}{|l|c|c|}
\hline \multirow{2}{*}{ Team } & \multicolumn{2}{|c|}{ Statistical Category } \\
\cline { 2 - 3 } & PS/G & PA/G \\
\hline Žalgiris Kaunas statistics & $+2.0(+5.7)$ & $-0.5(-5.8)$ \\
\hline Opponent statistics & $-2.8(-7.1)$ & $+3.6(+6.5)$ \\
\hline \multirow{2}{*}{ Žalgiris Kaunas statistics } & 3 PTA/G & 3 PTM/G \\
\hline Opponent statistics & $+0.3(+1.8)$ & $+0.5(+1.8)$ \\
\hline \hline & $+1.6(+1.4)$ & $+0.2(-0.9)$ \\
\hline Žalgiris Kaunas statistics & FTA/G & FTM/G \\
\hline Opponent statistics & $+1.9(+1.9)$ & $+1.3(+1.0)$ \\
\hline & $-0.3(-2.0)$ & $+0.2(-1.0)$ \\
\hline Žalgiris Kaunas statistics & \multicolumn{2}{|c|}{ AST/G } \\
\hline Opponent statistics & \multicolumn{2}{|c|}{$+0.8(+3.0)$} \\
\hline \hline & \multicolumn{2}{|c|}{$+0.5(-0.2)$} \\
\hline Žalgiris Kaunas statistics & \multicolumn{2}{|c|}{$-1.4(-2.9)$} \\
\hline Opponent statistics & \multicolumn{2}{|c|}{$-0.4(+0.1)$} \\
\hline
\end{tabular}

Key to acronyms:

$\mathrm{PS} / \mathrm{G}$ and $\mathrm{PA} / \mathrm{G}=$ points scored per game and points allowed per game.

3 PTA/G and $3 \mathrm{PTM} / \mathrm{G}=3$ points attempts per game and 3 points made per game.

FTA/G and FTM/G = free throws attempts per game and free throws made per game.

$\mathrm{AST} / \mathrm{G}=$ assists per game.

$\mathrm{TO} / \mathrm{G}=$ turnovers per game.

Source: authors' elaboration with data from Basketnews.lt (2020), Euroleague.net (2020a) and (2020b), Overbasket.com (2020).

As it is evident from the above, the basic indicators show that the team being investigated plays better in those environments (with attendances higher than season average) and consequently managed to hold its opposition to much lower standards as well. However, the main question is why is that the case? As it was already stated above and supported by a number of researchers (see, for example, Shea and Baker 2013; amongst others), points per game statistic is not a good predictor of wins; analytics argue that an offensive efficiency calculations could help predict victories more accurately. Authors of the current study strongly agree with the significance of offensive efficiency. That is because offensive efficiency is adjusted for pace and since teams trade possessions back and forth, it does not really matter how quickly they score. What matters is making the most out of every possession and forcing the opposing team to waste their possessions. 
As a result, the number of offensive possessions was calculated (using data available at Overbasket.com 2020). The team's total points scored divided by the possessions produces offensive efficiency value; numbers above 1.0 are generally considered an indication of good offence and potential to win.

Calculated offensive possession and offensive efficiency numbers provided some meaningful insights into Žalgiris Kaunas home court advantage. Offensive possessions were lower than team's season average during all 19 games and even 11 home wins. However, the team significantly improved its offensive efficiency ( +0.05 in all 19 games and +0.10 in wins), meaning that the home team was indeed making more out of its every offensive possession. So, for example, if Žalgiris has averaged almost 79 possessions, an increased efficiency of 0.10 amounted to almost 8 points - a significant margin in contemporary elite basketball and a meaningful indicator of a win (see additional details in Table 2).

Table 2. Key Statistical Categories of Žalgiris Kaunas Offensive Efficiency (during 2017-2018 and 2018-2019 Seasons)

\begin{tabular}{|l|c|}
\hline Statistical Category & Žalgiris Kaunas Statistics \\
\hline Offensive possessions (average) & 79.3 \\
\hline Offensive efficiency (average) & 1.00 \\
\hline Offensive possessions (19 home games) & 77.9 \\
\hline Offensive efficiency (19 home games) & 1.05 \\
\hline \hline Offensive possessions (11 home wins) & 78.6 \\
\hline Offensive efficiency (11 home wins) & 1.10 \\
\hline
\end{tabular}

Source: authors' elaboration with data from Basketnews.lt (2020), Euroleague.net (2020a) and (2020b), Overbasket.com (2020).

\section{Conclusion}

Harris and Roebber (2019, p. 1) concluded that home advantage is "unanimously accepted as a key factor" to the success in a game for any team. Basketball is no exception to this - it is widely accepted that playing on one's home-court provides an advantage; players and coaches speak about its importance and teams compete for it in the lead to the playoffs. What is yet to be fully understood is the value of this competitive edge. Presumably factors such as familiarity with the environment and reinforcement from a friendly crowd - facets of the game that are not directly measured - have positive implications. Other underlying factors such as territoriality, culture, history, and playing conditions are either ambiguous or unlikely to have significant influence in a modern, indoor sport such as NBA basketball (Swartz and Arce 2014).

Similar positive implications are applicable to European basketball too as Pollard and Gomez (2013) argue that the average home advantage reaches 60.7 per cent in their study of 35 European national basketball leagues. Adding to these findings, Volossovitch (2017) stresses the need to take into account the actual venue where the basketball game is played when looking at a team's performance - an aspect which current paper attempted to do. Having said that, the home court 
advantage cannot, on its own, isolated from other factors, win games - but it is clearly an adjunct to other performance success indices in basketball.

It is evident that home crowd has a positive impact on Žalgiris Kaunas performance (they played in front of a sold-out arena in so many instances during the seasons that were analysed). The performance of Žalgiris Kaunas team improved virtually across every offensive key statistical category: the team was scoring more points, making (and taking /attempting) more 3-points and free throws (most efficient shots in modern basketball). In addition, Žalgiris Kaunas team displayed better teamwork by registering more assists than the opposition and less turnovers.

However, the most important finding of this study was that Žalgiris Kaunas team has displayed increased offensive efficiency numbers - widely recognized as the key determinant of wins. To simply put, in those home games that were attended by more fans than team's regular attendance, Žalgiris Kaunas has managed to achieve a better outcome from the same amount of input. Whether it was because the opponents were competing more poorly or the home team was executing its game plan more accurately, it should be explored in greater detail in future research.

One fact is certain: while Žalgiris Kaunas team's performance has improved when playing at home, compared to the opposite team, as evidenced by certain statistical categories for the seasons investigated (2017-2018 and 2018-2019), there is a need for further research into the effectiveness of home (and away) team performances - it looks like the match results and, generally, the team performance, are influenced by home-field factors related to crowd and familiarity effects, which require more specific attention (Carmichael and Thomas 2005).

\section{References}

Basketnews.lt (2020) Eurolyga - Statistika. (Euroleague - Statistics). Retrieved from: http s://www.basketnews.lt/lygos/25-eurolyga/statistika.html?fgroup=teams\&fseason=201 $7 \& \mathrm{fmonth}=0 \&$ stage $=0 \& \mathrm{fpos}=$ att $\&$ sort $=$ average \&games_type $=$ all. $[$ Accessed 10 June 2020.]

Bocskocsky A, Ezekowitz J, Stein C (2014) The hot hand: a new approach to an old "fallacy". $8^{\text {th }}$ Annual MIT Sloan Sports Analytics Conference, 1-10.

Bray S, Widmeyer W (2008) Athletes' perceptions of the home advantage: an investigation of perceived causal factors. Journal of Sport Behaviour 23(1): 1-10.

Carmichael F, Thomas D (2005) Home-field effect and team performance: evidence from english premiership football. Journal of Sports Economics 6(3): 264-281.

Castel A, Rossi A, McGillivray S (2012) Beliefs about the "hot hand" in basketball across the adult life span. Psychology and Aging 27(3): 601-605.

Clarke S (2005) Home advantage in the Australian football league. Journal of Sports Sciences 23(4): 375-385.

Courneya K, Carron A (1992) The home advantage in sport competitions: a literature review. Journal of Sport and Exercise Psychology 14(1): 13-27.

Dogan I, Isik O, Ersoz Y (2016) Examining the Turkish men's professional basketball team's success according to game-related statistics with discriminant analysis. International Journal of Performance Analysis in Sport 16(3): 829-836. 
Entine O, Small D (2008) The role of rest in the NBA home-court advantage. Journal of Quantitative Analysis in Sports 4(2): 1-9.

Eurohoops.net (2019) The first ever Euroleague players poll. Retrieved from: https:// www.eurohoops.net/en/trademarks/879089/the-first-ever-euroleague-players-poll/9/. [Accessed 5 November 2019].

Euroleague.net (2020a) Game center. Retrieved from: https://www.euroleague.net/competi tion/teams/showteam?clubcode=ZAL\&seasoncode=E2017\#!games. [Accessed 6 June 2020.]

Euroleague.net (2020b) Game center/statistics. Retrieved from: https://www.euroleague. net $/$ main/statistics?mode $=$ Leaders\&entity $=$ Clubs\&seasonmode $=$ Single\&seasoncode $=$ E2017\&cat=FreeThrowsAttempted\&agg=Accumulated. [Accessed 6 June 2020.]

Euroleague.net (2020c) Žalgiris Kaunas - did you know that? Retrieved from: https://ww w.euroleague.net/final-four/belgrade-2018/news/i/8pfkqbnpy7prpg4t/zalgiris-kaunas -did-you-know-that. [Accessed 7 June 2020.]

Franks A, Miller A, Bornn L, Goldsberry K (2015) Counterpoints: advanced defensive metrics for NBA basketball. $9^{\text {th }}$ Annual MIT Sloan Sports Analytics Conference, 1-8.

Fylaktakidou A, Tsamourtzis E, Zaggelidis G (2011) The turnovers analysis to the women's National League basketball games. Sports Science Review XX(3-4): 69-83.

Garcia J, Ibanez S, Martinez De Santos R, Leite N, Sampaio J (2013) Identifying basketball performance indicators in regular season and playoff games. Journal of Human Kinetics 36(1): 161-168.

Garcia RJ, Canadas AM, Antunez MA (2015) Efectos de la asistencia, densidad de la misma y la capacidad del pabellonen las victoriasconseguidasen casa en function de la conferenciaen la NBA. (Effects of attendance, crowd density and capacity of arena in home advantage according to NBA conference). Cuadernos de Psicologia del Deporte 15(3): 175-180.

Glockner A (2016) Chasing perfection: a behind-the-scenes look at the high-stakes game of creating an NBA champion. Boston, MA: Da Capo.

Gomez M, Pollard R (2011) Reduced home advantage for basketball teams from capital cities in Europe. European Journal of Sport Science 11(2): 143-148.

Gomez M, Lorenzo A, Sampaio J, Ibanez S, Ortega E (2008) Game-related statistics that discriminated winning and losing teams from the Spanish men's professional basketball teams. Collegium Antropologicum 32(2): 315-319.

Harris A, Roebber P (2019) NBA team home advantage: identifying key factors using an artificial neural network. PLoSONE 14(7): 1-9.

Harrison K, Bukstein S (2017) Sport business analytics: using data to increase revenue and improve operational efficiency. Boca Raton, FL: CRC Press.

Harville D, Smith M (1994) The home-court advantage: how large is it and does it vary from team to team? The American Statistician 48(1): 22-28.

Ibanez S, Sampaio J, Saenz-Lopez P, Gimenez J, Janeira M (2003) Game statistics discriminating the final outcome of junior world basketball championship matches (Portugal 1999). Journal of Human Movement Studies 45(1): 1-19.

Jones M (2013) The home advantage in individual sports: an augmented review. Psychology of Sport and Exercise 14(3): 397-404.

Jones M (2018) Differences in home advantage between sports. Psychology of Sport and Exercise 34(Jan): 61-69.

Jones I, Gratton C (2015) Research methods for sport studies. Abingdon: Routledge.

Kaplan S, Ramamoorthy V, Gupte C, Sagar A, Premkumar D, Wilbur J et al. (2019) The economic impact of NBA superstars: evidence from missed games using ticket microdata from a secondary marketplace. $13^{\text {th }}$ Annual MIT Sloan Sports Analytics Conference, 1-30. 
Koning R (2005) Home advantage in speed skating: evidence from individual data. Journal of Sports Sciences 23(4): 417-427.

Koning R (2011) Home advantage in professional tennis. Journal of Sports Sciences 29(1): 19-27.

Kozy J (2011) A game-theoretic analysis of home court advantage and optimal offensive strategy in basketball. University of Akron/Ohio LINK Electronic Theses and Dissertations. Retrieved from: https://etd.ohiolink.edu/pg_10?0::NO:10:P10_ACCE SSION_NUM:akron1306497821\#abstract-files. [Accessed 8 June 2020.]

Lewis M (2003) Moneyball: the art of winning an unfair game. New York, NY: W.W. Norton \& Company.

Madrigal R, James J (1999) Team quality and home advantage. Journal of Sport Behaviour 22(3): 381-398.

McAndrew F (1992) The home advantage in individual sports. The Journal of Social Psychology 133(3): 401-403.

Melnick MJ (2001) Relationship between team assists and win-loss record in the National Basketball Association. Perceptual and Motor Skills 92(2): 595-602.

Mondello M, Kamke C (2014) The introduction and application of sports analytics in professional sport organizations. Journal of Applied Sport Management 6(2): 1-12.

Moore J, Brylinsky J (1995) Facility familiarity and the home advantage. Journal of Sport Behaviour 18(4): 302-311.

Nevill A, Holder R (1999) Home advantage in sport: an overview of studies on the advantage of playing at home. Sports Medicine 28(4): 221-236.

Oliver D (2004) Basketball on paper: rules and tools for performance analysis. Dulles, VA: Potomac Books.

Overbasket.com (2020) Žalgiris Kaunas Stats by game. Retrieved from: http://overbasket. com/rsteams.php?tab=30\&year=2018\&cmp=EL\&shteam=ZAL [Accessed 7 June 2020.]

Pollard R, Gomez M (2013) Variations in home advantage in the national basketball leagues of Europe. Revista de Psicologia del Deporte 22(1): 263-266.

Pomeroy K (2012) Myth of home-court advantage. ESPN Report. Retrieved from: https:// www.espn.com/mens-college-basketball/insider/story/_id/7532021/ken-pome roybest-home-court-advantage-kansas-kentucky-duke-ncb. [Accessed 16 October 2019.]

Real Madrid (2019) "We will have to play well and move the ball around to beat Žalgiris", stated Thompkins. Retrieved from: https://www.realmadrid.com/ en/news/2017/01/la so-\%E2\% 80\%9Cwe-will-have-to-play-with-great-intensity-in-kaunas\%E2\%80\%9D. [Accessed 5 November 2019.]

Ross K (2017) Classroom investigations of recent research concerning the hot hand phenomenon. Journal of Statistics Education 25(3): 145-157.

Runrepeat.com (2019) The most popular Euroleague teams. Retrieved from: https://runre peat.com/the-most-popular-euroleague-teams. [Accessed 7 June 2020.]

Sampaio J (2003) Importance of free-throw performance in game outcome during the final series of basketball play-offs. International Journal of Applied Sports Sciences 15(2): 9-16.

Sampaio J, Janeira M (2003) Statistical analyses of basketball team performance: understanding teams' wins and losses according to a different index of ball possessions. International Journal of Performance Analysis in Sport 3(1): 40-49.

Sarlis V, Tjortjis C (2020) Sports analytics - Evaluation of basketball players and team performance. Information Systems 93(Nov): 1-19.

Schwartz B, Barsky S (1977) The home advantage. Social Forces 55(3): 641-661.

Shea S, Baker C (2013) Basketball analytics: objective and efficient strategies for understanding how teams win. Lake St. Louis, MO: Advanced Metrics. 
Smith R (2005) Disconnects between popular discourse and home advantage research: what can fans and media tell us about the home advantage phenomenon? Journal of Sports Sciences 23(4): 351-364.

Snyder E, Purdy D (1985) The home advantage in collegiate basketball. Sociology of Sport Journal 2(4): 352-356.

Swartz T, Arce A (2014) New insights involving home team advantage. International Journal of Sports Science and Coaching 9(4): 681-692.

Talkbasket.net (2019) The survey shows Zalgirio Arena as the leader in the Baltic region. Retrieved from: https://www.talkbasket.net/59551-the-survey-shows-zalgirio-arenaas-the-leader-in-the-baltic-region. [Accessed 7 June 2020.]

Troilo M, Bouchet A, Urban T, Sutton W (2016) Perception, reality, and the adoption of business analytics: evidence from North American professional sport organizations. Omega 59(A): 72-83.

Veal A, Darcy S (2014) Research methods in sport studies and sport management: a practical guide. Abingdon: Routledge.

Volossovitch A (2017) Research topics in basketball. In P Passos, D Araujo, A Volossovitch, Performance analysis in team sports. Abingdon: Routledge.

Watkins P (2013) Revisiting the home court advantage in college basketball. International Journal of Sport and Society 3(1): 33-42.

Yi D (2017) The home court advantage: evidence from Men's College basketball. Sport Journal 3(9): 1-1.

Zalgirioarena.lt (2011) Zalgiris arena plans and preparation for EuroBasket 2011. Retrieved from: https://zalgirioarena.lt/en/naujienos/2011/09/12/zalgiris-arena-planseurobasket-2011/. [Accessed 7 June 2020.]

Zalgirioarena.lt (2020) About Zalgirio Arena. History. Retrieved from: https://zalgirioare na.lt/en/zalgirio-arena/apie-arena/. [Accessed 7 June 2020.]

Zalgiris Kaunas (2019) Zalgirio Arena was voted the toughest arena to play by Euroleague players. Retrieved from: http://zalgiris.lt/en/news/bc-zalgiris/82995/. [Accessed 5 November 2019.] 
Appendix 1. Overview of Žalgiris Kaunas 19 Home Games, Attendance Figures and Main Statistical Indicators (Free Throws and 3 Points Shots) for 2017-2018 and 2018-2019 Seasons

\begin{tabular}{|c|c|c|c|c|c|c|c|}
\hline Date & Opponent & Result & Attendance & $\begin{array}{c}\text { Opponent } \\
\text { FT }\end{array}$ & $\begin{array}{l}\text { Žalgiris } \\
\text { FT }\end{array}$ & $\begin{array}{l}\text { Opponent } \\
\text { 3 PTS }\end{array}$ & $\begin{array}{c}\text { Žalgiris } \\
3 \text { PTS }\end{array}$ \\
\hline $\begin{array}{c}2017-12- \\
28\end{array}$ & $\begin{array}{l}\text { Olympiacos } \\
\text { Piraeus }\end{array}$ & $74: 68$ & 15480 & $13 / 16$ & $11 / 16$ & $9 / 27$ & $9 / 19$ \\
\hline $\begin{array}{c}\text { 2018-01- } \\
12 \\
\end{array}$ & $\begin{array}{l}\text { Unicaja } \\
\text { Malaga }\end{array}$ & $79: 77$ & 15392 & $11 / 13$ & $12 / 15$ & $12 / 28$ & $5 / 17$ \\
\hline $\begin{array}{l}\text { 2018-02- } \\
01\end{array}$ & $\begin{array}{c}\text { Maccabi Tel } \\
\text { Aviv }\end{array}$ & $99: 84$ & 14844 & $21 / 26$ & $13 / 21$ & $5 / 20$ & $14 / 23$ \\
\hline $\begin{array}{c}2018-02- \\
09\end{array}$ & $\begin{array}{c}\text { Khimki } \\
\text { Moscow } \\
\text { Region } \\
\end{array}$ & $74: 84$ & 15172 & $21 / 26$ & $24 / 28$ & $11 / 29$ & $6 / 17$ \\
\hline $\begin{array}{c}\text { 2018-03- } \\
01 \\
\end{array}$ & FC Barcelona & $90: 74$ & 14477 & $12 / 16$ & $14 / 21$ & $6 / 21$ & $10 / 24$ \\
\hline $\begin{array}{c}\text { 2018-03- } \\
09 \\
\end{array}$ & $\begin{array}{c}\text { Fenerbahce } \\
\text { Istanbul }\end{array}$ & $78: 85$ & 15238 & $25 / 25$ & $19 / 22$ & $8 / 18$ & $5 / 10$ \\
\hline $\begin{array}{c}2018-03- \\
20\end{array}$ & $\begin{array}{c}\text { AX Armani } \\
\text { Exchange } \\
\text { Milan }\end{array}$ & $77: 65$ & 13747 & $12 / 16$ & $19 / 31$ & $7 / 27$ & $2 / 9$ \\
\hline $\begin{array}{c}\text { 2018-03- } \\
30\end{array}$ & $\begin{array}{l}\text { CSKA } \\
\text { Moscow }\end{array}$ & $85: 73$ & 15525 & $10 / 12$ & $22 / 26$ & $5 / 21$ & $5 / 11$ \\
\hline $\begin{array}{c}2018-04- \\
24 \\
\end{array}$ & $\begin{array}{c}\text { Olympiacos } \\
\text { Piraeus }\end{array}$ & $80: 60$ & 14345 & $20 / 27$ & $20 / 25$ & $4 / 22$ & $4 / 16$ \\
\hline $\begin{array}{c}2018-04- \\
26 \\
\end{array}$ & $\begin{array}{c}\text { Olympiacos } \\
\text { Piraeus }\end{array}$ & 101:91 & 14411 & $31 / 38$ & $26 / 31$ & $10 / 26$ & $13 / 24$ \\
\hline $\begin{array}{c}2018-10- \\
12\end{array}$ & $\begin{array}{c}\text { Baskonia } \\
\text { Vitoria }\end{array}$ & $79: 87$ & 15107 & $11 / 14$ & $17 / 23$ & $12 / 28$ & $4 / 11$ \\
\hline $\begin{array}{l}\text { 2018-11- } \\
02\end{array}$ & Real Madrid & $79: 90$ & 15105 & $15 / 22$ & $5 / 10$ & $11 / 23$ & $4 / 9$ \\
\hline $\begin{array}{c}\text { 2018-11- } \\
16 \\
\end{array}$ & FC Barcelona & $85: 88$ & 15126 & $14 / 24$ & $18 / 23$ & $12 / 23$ & $5 / 22$ \\
\hline $\begin{array}{c}\text { 2018-12- } \\
21 \\
\end{array}$ & $\begin{array}{c}\text { Maccabi Tel } \\
\text { Aviv }\end{array}$ & $80: 73$ & 15168 & $7 / 10$ & $17 / 20$ & $10 / 31$ & $11 / 20$ \\
\hline $\begin{array}{c}\text { 2019-01- } \\
04 \\
\end{array}$ & $\begin{array}{c}\text { CSKA } \\
\text { Moscow } \\
\end{array}$ & $79: 84$ & 15205 & $20 / 25$ & $38 / 43$ & $8 / 25$ & $5 / 14$ \\
\hline $\begin{array}{c}\text { 2019-01- } \\
18 \\
\end{array}$ & $\begin{array}{c}\text { Panathinaikos } \\
\text { Athens }\end{array}$ & $82: 69$ & 15140 & $4 / 6$ & $19 / 21$ & $7 / 23$ & $7 / 15$ \\
\hline $\begin{array}{c}\text { 2019-03- } \\
22 \\
\end{array}$ & $\begin{array}{c}\text { Darussafaka } \\
\text { Istanbul } \\
\end{array}$ & $94: 67$ & 15178 & $7 / 10$ & $16 / 22$ & $2 / 17$ & $12 / 24$ \\
\hline $\begin{array}{c}\text { 2019-04- } \\
23 \\
\end{array}$ & $\begin{array}{c}\text { Fenerbahce } \\
\text { Istanbul }\end{array}$ & $57: 66$ & 15517 & $14 / 17$ & $11 / 16$ & $10 / 34$ & $6 / 17$ \\
\hline $\begin{array}{c}\text { 2019-04- } \\
25 \\
\end{array}$ & $\begin{array}{c}\text { Fenerbahce } \\
\text { Istanbul }\end{array}$ & $82: 99$ & 15177 & $10 / 11$ & $15 / 18$ & $15 / 22$ & $7 / 19$ \\
\hline
\end{tabular}

Source: authors' compilation with data from Euroleague.net (2020a), Euroleague.net (2020b), Basketnews.lt (2020). 